\title{
Combined ingestion of protein and carbohydrate improves protein balance during ultra-endurance exercise
}

Citation for published version (APA):

Koopman, R., Pannemans, D. L. E., Jeukendrup, A. E., Gijsen, A. P., Senden, J. M. G., Halliday, D., Saris, W. H., van Loon, L. J., \& Wagenmakers, A. J. M. (2004). Combined ingestion of protein and carbohydrate improves protein balance during ultra-endurance exercise. American Journal of Physiology : Endocrinology and Metabolism, 287(4), E712-720. https://doi.org/10.1152/ajpendo.00543.2003

Document status and date:

Published: 01/01/2004

DOI:

10.1152/ajpendo.00543.2003

Document Version:

Publisher's PDF, also known as Version of record

\section{Please check the document version of this publication:}

- A submitted manuscript is the version of the article upon submission and before peer-review. There can be important differences between the submitted version and the official published version of record. People interested in the research are advised to contact the author for the final version of the publication, or visit the DOI to the publisher's website.

- The final author version and the galley proof are versions of the publication after peer review.

- The final published version features the final layout of the paper including the volume, issue and page numbers.

Link to publication

\footnotetext{
General rights rights.

- You may freely distribute the URL identifying the publication in the public portal. please follow below link for the End User Agreement:

www.umlib.nl/taverne-license

Take down policy

If you believe that this document breaches copyright please contact us at:

repository@maastrichtuniversity.nl

providing details and we will investigate your claim.
}

Copyright and moral rights for the publications made accessible in the public portal are retained by the authors and/or other copyright owners and it is a condition of accessing publications that users recognise and abide by the legal requirements associated with these

- Users may download and print one copy of any publication from the public portal for the purpose of private study or research.

- You may not further distribute the material or use it for any profit-making activity or commercial gain

If the publication is distributed under the terms of Article $25 \mathrm{fa}$ of the Dutch Copyright Act, indicated by the "Taverne" license above, 


\section{Combined ingestion of protein and carbohydrate improves protein balance during ultra-endurance exercise \\ René Koopman, Daphne L. E. Pannemans, Asker E. Jeukendrup, Annemie P. Gijsen, Joan M. G. Senden, David Halliday, Wim H. M. Saris, Luc J. C. van Loon and Anton J. M. Wagenmakers \\ AJP - Endo 287:712-720, 2004. First published May 27, 2004; doi:10.1152/ajpendo.00543.2003}

You might find this additional information useful...

This article cites 37 articles, 25 of which you can access free at: http://ajpendo.physiology.org/cgi/content/full/287/4/E712\#BIBL

Updated information and services including high-resolution figures, can be found at: http://ajpendo.physiology.org/cgi/content/full/287/4/E712

Additional material and information about AJP - Endocrinology and Metabolism can be found at: http://www.the-aps.org/publications/ajpendo

This information is current as of February 23, 2005.

AJP - Endocrinology and Metabolism publishes results of original studies about endocrine and metabolic systems on any level of organization. It is published 12 times a year (monthly) by the American Physiological Society, 9650 Rockville Pike, Bethesda MD 20814-3991. Copyright @ 2005 by the American Physiological Society. ISSN: 0193-1849, ESSN: 1522-1555. Visit our website at http://www.the-aps.org/. 


\title{
Combined ingestion of protein and carbohydrate improves protein balance during ultra-endurance exercise
}

\author{
René Koopman, Daphne L. E. Pannemans, Asker E. Jeukendrup, Annemie P. Gijsen, Joan M. G. Senden, \\ David Halliday, Wim H. M. Saris, Luc J. C. van Loon, and Anton J. M. Wagenmakers \\ Department of Human Biology, Nutrition Research Institute Maastricht, \\ Maastricht University, 6200 MD Maastricht, The Netherlands
}

Submitted 1 December 2003; accepted in final form 25 May 2004

\begin{abstract}
Koopman, René, Daphne L. E. Pannemans, Asker E. Jeukendrup, Annemie P. Gijsen, Joan M. G. Senden, David Halliday, Wim H. M. Saris, Luc J. C. van Loon, and Anton J. M. Wagenmakers. Combined ingestion of protein and carbohydrate improves protein balance during ultra-endurance exercise. Am J Physiol Endocrinol Metab 287: E712-E720, 2004. First published May 27, 2004; 10.1152/ajpendo.00543.2003. - The aims of this study were to compare different tracer methods to assess whole body protein turnover during $6 \mathrm{~h}$ of prolonged endurance exercise when carbohydrate was ingested throughout the exercise period and to investigate whether addition of protein can improve protein balance. Eight endurancetrained athletes were studied on two different occasions at rest $(4 \mathrm{~h})$, during $6 \mathrm{~h}$ of exercise at $50 \%$ of maximal $\mathrm{O}_{2}$ uptake (in sequential order: $2.5 \mathrm{~h}$ of cycling, $1 \mathrm{~h}$ of running, and $2.5 \mathrm{~h}$ of cycling), and during subsequent recovery $(4 \mathrm{~h})$. Subjects ingested carbohydrate (CHO trial; $0.7 \mathrm{~g} \mathrm{CHO} \cdot \mathrm{kg}^{-1} \cdot \mathrm{h}^{-1}$ ) or carbohydrate/protein beverages $\left(\mathrm{CHO}+\mathrm{PRO}\right.$ trial; $0.7 \mathrm{~g} \mathrm{CHO} \cdot \mathrm{kg}^{-1} \cdot \mathrm{h}^{-1}$ and $\left.0.25 \mathrm{~g} \mathrm{PRO} \cdot \mathrm{kg}^{-1} \cdot \mathrm{h}^{-1}\right)$ at 30-min intervals during the entire study. Whole body protein metabolism was determined by infusion of $\mathrm{L}-\left[1-{ }^{13} \mathrm{C}\right]$ leucine, L- $\left[{ }^{2} \mathrm{H}_{5}\right]$ phenylalanine, and $\left[{ }^{15} \mathrm{~N}_{2}\right]$ urea tracers with sampling of blood and expired breath. Leucine oxidation increased from rest to exercise $[27 \pm 2.5$ vs. $74 \pm 8.8(\mathrm{CHO})$ and $85 \pm 9.5$ vs. $200 \pm 16.3 \mathrm{mg}$ protein $\left.\cdot \mathrm{kg}^{-1} \cdot \mathrm{h}^{-1}(\mathrm{CHO}+\mathrm{PRO}), P<0.05\right]$, whereas phenylalanine oxidation and urea production did not increase with exercise. Whole body protein balance during exercise with carbohydrate ingestion was negative $(-74 \pm 8.8,-17 \pm 1.1$, and $-72 \pm 5.7 \mathrm{mg}$ protein $\left.\cdot \mathrm{kg}^{-1} \cdot \mathrm{h}^{-1}\right)$ when $\mathrm{L}-\left[1-{ }^{13} \mathrm{C}\right]$ leucine, $\mathrm{L}-\left[{ }^{2} \mathrm{H}_{5}\right]$ phenylalanine, and $\left[{ }^{15} \mathrm{~N}_{2}\right]$ urea, respectively, were used as tracers. Addition of protein to the carbohydrate drinks resulted in a positive or less-negative protein balance $(-32 \pm 16.3,165 \pm 4.6$, and $151 \pm 13.4 \mathrm{mg}$ protein $\left.\cdot \mathrm{kg}^{-1} \cdot \mathrm{h}^{-1}\right)$ when $\mathrm{L}-\left[1-{ }^{13} \mathrm{C}\right]$ leucine, $\mathrm{L}-\left[{ }^{2} \mathrm{H}_{5}\right]$ phenylalanine, and $\left[{ }^{15} \mathrm{~N}_{2}\right]$ urea, respectively, were used as tracers. We conclude that, even during $6 \mathrm{~h}$ of exhaustive exercise in trained athletes using carbohydrate supplements, net protein oxidation does not increase compared with the resting state and/or postexercise recovery. Combined ingestion of protein and carbohydrate improves net protein balance at rest as well as during exercise and postexercise recovery.
\end{abstract}

protein metabolism; dietary supplements; protein intake

IN THE NINETEENTH CENTURY, skeletal muscle protein was thought to be the main fuel used to generate energy for muscle contractions (33). However, controlled nitrogen balance studies invalidated the proposed hypothesis, inasmuch as they showed no substantial increase in nitrogen loss during and/or after prolonged exercise $(9,14)$. Since then, various methods have been applied to investigate the effects of exercise on protein metabolism. This has resulted in many discrepant

Address for reprint requests and other correspondence: R. Koopman, Dept. of Human Biology, Maastricht Univ., PO Box 616, 6200 MD Maastricht, The Netherlands (E-mail: R.Koopman@HB.unimaas.nl). findings in the literature, which are due in part to differences in the methodology employed and in part to the conditions under which different exercise interventions have been performed.

Since the introduction of stable isotope tracers in metabolic research, various methods have been applied to study whole body protein metabolism. Most studies have used plasma $\mathrm{L}-\left[1-{ }^{13} \mathrm{C}\right]$ leucine kinetics as a model for whole body protein metabolism. Whereas several studies have reported increases in whole body protein degradation during exercise $(23,25,39,40)$, others have failed to observe such changes $(6,26)$. Wolfe et al. (39) measured the rate of appearance of ${ }^{13} \mathrm{CO}_{2}$ in the expired breath from infused ${ }^{13} \mathrm{C}$-labeled leucine and reported a threefold increase in leucine oxidation rates during exercise. The latter was shown to occur in the absence of a change in total leucine flux, which implies that the observed increase in protein breakdown was accompanied by a reduction in the rate of protein synthesis. Another tracer method that has been developed to determine whole body protein metabolism, without the necessity of analyzing breath gases, is the use of $\mathrm{L}^{-}\left[{ }^{2} \mathrm{H}_{5}\right]$ phenylalanine according to the model of Clarke and Bier (10) and Thompson et al. (27). However, that method has not been applied to investigate the effect of prolonged endurance exercise. Studies applying $\left[{ }^{15} \mathrm{~N}\right]$ urea to determine the rate of urea production as a measure of the amount of amino acids that are liberated by net protein degradation (degradation synthesis) and oxidized (with conversion of the amino group to urea) during exercise have not confirmed the catabolic nature of prolonged endurance exercise $(7,39)$.

The reports using urea as a tracer indicate that protein synthesis and degradation rates do not change during endurance-type activities. However, nitrogen balance data from field studies suggest that prolonged endurance exercise, leading to glycogen depletion, is accompanied by a substantial increase in net protein breakdown (13). Therefore, activation of the branched-chain $\alpha$-keto acid dehydrogenase complex, the enzyme responsible for leucine oxidation in the muscle, has been shown to increase during exercise when glycogen stores are low $(34,35)$. During competition, many endurance athletes (e.g., cyclists, triathletes, and ultra-marathon runners) exercise for $>5 \mathrm{~h}$ at relatively high workloads and deplete their glycogen stores to a large extent. However, whole body protein turnover measurements using multiple amino acid tracers have not been performed during such prolonged exhaustive exercise activity.

The costs of publication of this article were defrayed in part by the payment of page charges. The article must therefore be hereby marked "advertisement" in accordance with 18 U.S.C. Section 1734 solely to indicate this fact. 
Endurance-trained athletes try to optimize carbohydrate availability through carbohydrate ingestion before, during, and after exercise. However, most studies measuring protein turnover during exercise have been performed after an overnight fast and with nutritional interventions generally applied during the postexercise recovery phase. Little information is available about the effects of carbohydrate or carbohydrate + protein supplementation on protein metabolism during exercise. The available literature indicates that ingestion of carbohydrate + protein in the postexercise recovery phase improves net protein balance $(12,22)$, at least after resistance exercise $(2,3,24,28$, 29). Ingestion of such a substrate mixture during exercise could possibly also affect protein balance during and after prolonged endurance exercise.

In the present study, we determined whole body protein synthesis and degradation rates at rest, during prolonged exhaustive exercise, and during subsequent recovery. A multiple-tracer approach applying L- $\left[1-{ }^{13} \mathrm{C}\right]$ leucine, $\mathrm{L}-\left[{ }^{2} \mathrm{H}_{5}\right]$ phenylalanine, and $\left[{ }^{15} \mathrm{~N}_{2}\right]$ urea infusions was chosen to investigate whether there are differences in outcome, depending on the applied tracer model. These studies were performed in a laboratory setting that resembles real-life endurance exercise competition in elite triathletes, combining $6 \mathrm{~h}$ of exercise with regular carbohydrate supplementation. In addition, we investigated whether the addition of protein to carbohydrate ingestion can improve net protein balance during exercise and subsequent recovery compared with the ingestion of only carbohydrate.

\section{METHODS}

Subjects. Eight well-trained male subjects [age $=31 \pm 3 \mathrm{yr}$, height $=1.84 \pm 0.03 \mathrm{~m}$, weight $=72.4 \pm 2.3 \mathrm{~kg}$, body mass index $=$ $21.4 \pm 0.3 \mathrm{~kg} / \mathrm{m}^{2}, \%$ body fat $=9.6 \pm 0.8 \%$, fat-free mass $=65.7 \pm$ $1.3 \mathrm{~kg}$, maximal workload capacity $\left(\mathrm{W}_{\max }\right)=383 \pm 13 \mathrm{~W}$, maximal $\mathrm{O}_{2}$ uptake $\left(\mathrm{V}_{2}\right.$ max $\left.)=4.9 \pm 0.21 / \mathrm{min}\right]$ participated in the study. Subjects trained $\sim 15 \mathrm{~h} /$ wk ( $3 \mathrm{~h}$ of swimming, $7 \mathrm{~h}$ of cycling, and $5 \mathrm{~h}$ of running) and had a $>5$-yr training history. Subjects were informed about the nature and risks of the procedures before their written informed consent was obtained. The study was approved by the local medical ethical committee of the Academic Hospital Maastricht.

Pretesting. $\dot{\mathrm{V}}_{2}$ max and $\mathrm{W}_{\max }$ were measured on an electronically braked cycle ergometer (Lode Excalibur, Groningen, The Netherlands) during an incremental exhaustive exercise test (17) $1 \mathrm{wk}$ before the first trial to determine $45 \% \mathrm{~W}_{\max }\left(179 \pm 8.6 \mathrm{~W}, \sim 50 \% \dot{\mathrm{V}}_{2} \max \right)$, which was applied in these studies. Maximum running velocity was determined on a motor-driven treadmill with a $1 \%$ incline (to represent outdoor running) using an incremental exhaustive exercise test to determine the $45 \%$ maximal running velocity $(11.0 \pm 0.3 \mathrm{~km} / \mathrm{h}$, $\sim 50 \% \dot{\mathrm{V}}_{2}$ max $)$. After a 5 -min warm-up at $10 \mathrm{~km} / \mathrm{h}$, speed was increased every $3 \mathrm{~min}$ by $2 \mathrm{~km} / \mathrm{h}$ and from a heart rate of $85 \%$ of maximal heart rate with $1 \mathrm{~km} / \mathrm{h}$ every $3 \mathrm{~min}$ until the subject was unable to continue.

Diet and activity before testing. All subjects were instructed not to consume any products with a high natural abundance of ${ }^{13} \mathrm{C}$ (carbohydrates derived from $\mathrm{C}_{4}$ plants: corn and sugar cane) $1 \mathrm{wk}$ before the first trial and during the entire test period. This has been shown to minimize possible shifts in background enrichment due to changes in endogenous substrate utilization (36). All subjects were also instructed to refrain from heavy physical exercise and to maintain normal dietary habits for 3 days before each trial. In addition, we asked subjects to record their food intake for $48 \mathrm{~h}$ before the start of the first experimental trial and to consume exactly the same food $48 \mathrm{~h}$ before the start of the second test.
Studies. All subjects were studied on two different occasions. Each test day consisted of three parts, during which whole body protein turnover and whole body urea production rates were measured at rest, during prolonged exercise, and during subsequent recovery. Via a randomized crossover design, subjects received beverages containing carbohydrate $(\mathrm{CHO})$ or carbohydrate with protein hydrolysate $(\mathrm{CHO}+\mathrm{PRO})$ during each trial. An outline of the study design is presented in Fig. 1.

Protocol. The subjects reported to the laboratory at 7 AM after an overnight fast. A Teflon catheter (Baxter, Utrecht, The Netherlands) was inserted into an antecubital vein of one arm for blood sampling; another catheter was inserted in the contralateral arm for isotope infusion. A resting blood sample was drawn, and expired breath samples were collected into Vacutainer tubes (Becton Dickinson, Meylan, France) to measure baseline enrichments. Thereafter, the bicarbonate pool was primed with a single intravenous dose of $\mathrm{NaH}^{13} \mathrm{CO}_{3}(5.9 \mu \mathrm{mol} / \mathrm{kg})$, which was followed by priming with $\mathrm{L}-\left[1-{ }^{13} \mathrm{C}\right]$ leucine $(7.6 \mu \mathrm{mol} / \mathrm{kg}), \mathrm{L}-\left[{ }^{2} \mathrm{H}_{5}\right]$ phenylalanine $(3.0 \mu \mathrm{mol} / \mathrm{kg})$, $\left[{ }^{15} \mathrm{~N}_{2}\right]$ urea $(88 \mu \mathrm{mol} / \mathrm{kg})$, and L- $\left[{ }^{2} \mathrm{H}_{4}\right]$ tyrosine $(0.46 \mu \mathrm{mol} / \mathrm{kg})$. Thereafter (time 0$)$, continuous infusion of $\mathrm{L}-\left[1-{ }^{13} \mathrm{C}\right]$ leucine (7.6 $\left.\mu \mathrm{mol} \cdot \mathrm{kg}^{-1} \cdot \mathrm{h}^{-1}\right), \quad \mathrm{L}-\left[{ }^{2} \mathrm{H}_{5}\right]$ phenylalanine $\left(3 \mu \mathrm{mol} \cdot \mathrm{kg}^{-1} \cdot \mathrm{h}^{-1}\right)$, and $\left[{ }^{15} \mathrm{~N}_{2}\right]$ urea $\left(88 \mu \mathrm{mol} \cdot \mathrm{kg}^{-1} \cdot \mathrm{h}^{-1}\right)$ was started via a calibrated pump (model 560, IVAC, San Diego, CA) and continued for $14 \mathrm{~h}$. After the start of the tracer infusion, subjects rested for $4 \mathrm{~h}$ (resting period). Subsequently, subjects exercised for $6 \mathrm{~h}$ at a moderate intensity $(45 \%$ $\mathrm{W}_{\max }$ ), starting with $2.5 \mathrm{~h}$ of cycling followed by $1 \mathrm{~h}$ of treadmill running and another $2.5 \mathrm{~h}$ of cycling exercise. Subjects were not allowed to rest between the different exercise bouts, except for the time necessary to change from ergometer to treadmill and back to ergometer. After cessation of exercise, subjects rested for $4 \mathrm{~h}$ (recovery). During the preexercise resting period and the postexercise recovery phase, breath and blood samples were obtained every 30 and $60 \mathrm{~min}$, respectively. During cycling exercise periods, blood and breath samples were collected every $30 \mathrm{~min}$, and $\mathrm{O}_{2}$ uptake and $\mathrm{CO}_{2}$ output were measured (Oxycon- $\beta$, Mijnhardt, Bunnik, The Netherlands) at 30-min intervals for $5 \mathrm{~min}$.

Beverages. Directly after the start of the stable isotope infusion and every $30 \mathrm{~min}$ throughout the entire trial (before, during, and after exercise), subjects received a beverage volume of $4 \mathrm{ml} / \mathrm{kg}$ to ensure a given dose of $0.7 \mathrm{~g} \cdot \mathrm{kg}^{-1} \cdot \mathrm{h}^{-1}$ carbohydrates (maltodextrin) in the control trial $(\mathrm{CHO})$ and $0.7 \mathrm{~g} \cdot \mathrm{kg}^{-1} \cdot \mathrm{h}^{-1}$ carbohydrate and 0.25 $\mathrm{g} \cdot \mathrm{kg}^{-1} \cdot \mathrm{h}^{-1}$ protein hydrolysate in the $\mathrm{CHO}+\mathrm{PRO}$ trial. The drinks were prepared by Quest International (Naarden, The Netherlands). $\mathrm{L}-\left[{ }^{2} \mathrm{H}_{5}\right]$ phenylalanine and $\mathrm{L}-\left[1-{ }^{13} \mathrm{C}\right]$ leucine enrichment in the bever-

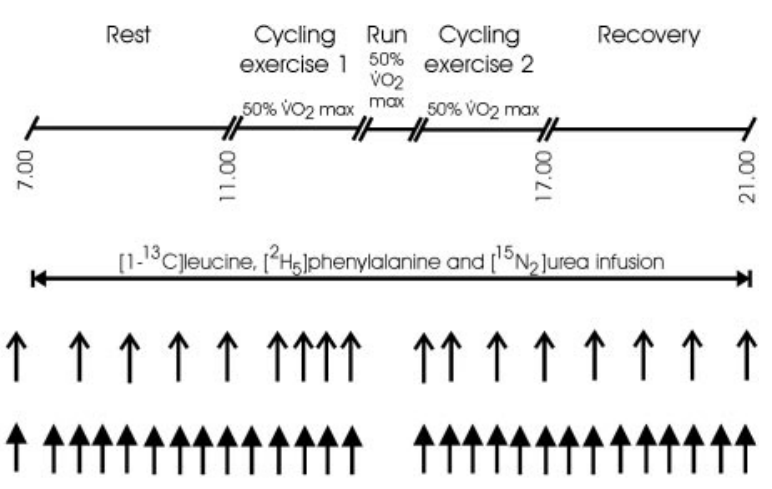

$\mathrm{CO}_{2}$

production

Fig. 1. Schematic outline of study protocol. Every $30 \mathrm{~min}$ throughout the entire test, subjects received a beverage volume of $4 \mathrm{ml} / \mathrm{kg}$ to ensure a given dose of $0.7 \mathrm{~g} \cdot \mathrm{kg}^{-1} \cdot \mathrm{h}^{-1}$ carbohydrate (maltodextrin) in the control trial (CHO) and $0.7 \mathrm{~g} \cdot \mathrm{kg}^{-1} \cdot \mathrm{h}^{-1}$ carbohydrate and $0.25 \mathrm{~g} \cdot \mathrm{kg}^{-1} \cdot \mathrm{h}^{-1}$ protein hydrolysate in the $\mathrm{CHO}+\mathrm{PRO}$ trial. $\mathrm{V}_{2} \max$, maximal $\mathrm{O}_{2}$ uptake. 
ages was measured using GC-MS and did not differ from the $\mathrm{L}-\left[{ }^{2} \mathrm{H}_{5}\right]$ phenylalanine and $\mathrm{L}-\left[1-{ }^{13} \mathrm{C}\right]$ leucine enrichment in the plasma background samples. Therefore, beverage ingestion did not alter plasma enrichment, and corrections were not required. The composition of the beverages was as follows: $80 \mathrm{~g} / \mathrm{l}$ maltodextrin, $25 \mathrm{~g} / \mathrm{l}$ glucose syrup, $0.3 \mathrm{~g} / 1$ sodium benzoate, $2.25 \mathrm{~g} / \mathrm{l}$ citrus compound, 1 $\mathrm{g} / \mathrm{l}$ citric acid, and $0.2 \mathrm{~g} / \mathrm{l}$ ascorbic acid with or without $30 \mathrm{~g} / \mathrm{l}$ rice hydrolysate (Hyprol Dev 8115, Quest International). The amino acid profile of the rice hydrolysate is shown in Table 1.

Analyses. Blood samples were collected in EDTA-containing tubes and centrifuged at $1,000 \mathrm{~g}$ and $4^{\circ} \mathrm{C}$ for $5 \mathrm{~min}$. Aliquots of plasma were frozen in liquid nitrogen and stored at $-80^{\circ} \mathrm{C}$. Plasma $\left[1-{ }^{13} \mathrm{C}\right] \alpha-$ ketoisocaproate $(\alpha-\mathrm{KIC})$ enrichment was measured using a quinoxalinoltrimethylsilyl derivate $(31)$, whereas $\mathrm{L}-\left[{ }^{2} \mathrm{H}_{5}\right]$ phenylalanine and $\mathrm{L}-\left[{ }^{2} \mathrm{H}_{4}\right]$ tyrosine enrichments were measured using their $t$-butyldimethylsilyl derivates on a GC-MS (Finnigan, Incos XL, Bremen, Germany) (27). Plasma $\left[{ }^{15} \mathrm{~N}_{2}\right]$ urea enrichment was measured using the $N, N^{\prime}$-bistrimethylsilyl derivate of urea on a GC-MS (39). Breath ${ }^{13} \mathrm{CO}_{2}$ enrichment in the expired air was measured by GC continuousflow isotope ratio MS (MAT-252, Finnigan).

Statistics. Values are means \pm SE. To compare tracer kinetics and protein synthesis and degradation rates between the different interventions over time, a two-way repeated-measures ANOVA was used with subject and treatment as factors. Scheffé's post hoc test was applied in case of a significant $F$-ratio to locate specific differences. Student's $t$-tests for paired observations were used to compare differences in protein synthesis, breakdown, oxidation, net balance, and urea production between the $\mathrm{CHO}$ and $\mathrm{CHO}+$ PRO trials. Significance was set at the 0.05 level of confidence.

\section{RESULTS}

Tracer kinetics. Plasma L- $\left[{ }^{2} \mathrm{H}_{5}\right]$ phenylalanine and L- $\left[{ }^{2} \mathrm{H}_{4}\right]$ tyrosine enrichment, plasma $\left[1-{ }^{13} \mathrm{C}\right] \alpha$-KIC enrichment, breath ${ }^{13} \mathrm{CO}_{2}$ enrichment, and plasma $\left[{ }^{15} \mathrm{~N}_{2}\right]$ urea enrichment are shown in Fig. 2. Plasma L- $\left[{ }^{2} \mathrm{H}_{5}\right]$ phenylalanine, L- $\left[{ }^{2} \mathrm{H}_{4}\right]$ tyrosine, and $\left[1-{ }^{13} \mathrm{C}\right] \alpha$-KIC reached a steady state after $2 \mathrm{~h}$ of infusion. Breath ${ }^{13} \mathrm{CO}_{2}$ enrichment was significantly lower during exercise $(P<0.05)$ than at rest and during postexercise recovery. Plasma $\left[{ }^{15} \mathrm{~N}_{2}\right]$ urea enrichment slightly increased over time in the CHO trial, with significantly higher plasma $\left[{ }^{15} \mathrm{~N}_{2}\right]$ urea

Table 1. Amino acid composition of the protein hydrolysate

\begin{tabular}{ll}
\hline \multicolumn{1}{c}{ Amino Acids } & Rice Hydrolysate \\
\hline L-Arginine (Arg) & 5.6 \\
L-Histidine (His) & 1.5 \\
L-Asparagnine (Asn) & 4.1 \\
L-Glutamine (Gln) & 7.7 \\
L-Lysine (Lys) & 2.8 \\
L-Glycine (Gly) & 2.7 \\
L-Alanine (Ala) & 3.5 \\
L-Tryptophan (Trp) & 0.6 \\
L-Serine (Ser) & 3.4 \\
L-Proline (Pro) & 2.4 \\
L-Valine (Val) & 3.9 \\
L-Threonine (Thr) & 2.4 \\
L-Cysteine (Cys) & 0.6 \\
L-Isoleucine (Ile) & 2.8 \\
L-Leucine (Leu) & 5.2 \\
L-Aspartate (Asp) & 2.4 \\
L-Glutamate (Glu) & 4.5 \\
L-Methionine (Met) & 1.4 \\
L-Phenylalanine (Phe) & 3.6 \\
L-Tyrosine (Tyr) & 3.3 \\
\hline
\end{tabular}

Values are expressed in $\mathrm{g} / 100 \mathrm{~g}$ dry product. enrichment during recovery than during preexercise rest $(P<$ 0.05). In contrast, in the $\mathrm{CHO}+\mathrm{PRO}$ trial, plasma $\left[{ }^{15} \mathrm{~N}_{2}\right]$ urea enrichment remained constant throughout the trial. In the $\mathrm{CHO}+$ PRO trial, plasma L- $\left[{ }^{2} \mathrm{H}_{5}\right]$ phenylalanine, L- $\left[{ }^{2} \mathrm{H}_{4}\right]$ tyrosine, $\left[1-{ }^{13} \mathrm{C}\right] \alpha-\mathrm{KIC}$, and $\left[{ }^{15} \mathrm{~N}_{2}\right]$ urea enrichments were significantly lower than in the $\mathrm{CHO}$ trial $(P<0.05)$. Breath ${ }^{13} \mathrm{CO}_{2}$ enrichment was elevated in the $\mathrm{CHO}+\mathrm{PRO}$ trial compared with the CHO trial $(P<0.05)$.

Phenylalanine model. Protein flux was similar at rest, during exercise, and during postexercise recovery in the $\mathrm{CHO}$ trial $(176 \pm 6,170 \pm 6,172 \pm 7$, and $162 \pm 15 \mathrm{mg}$ protein $\cdot$ $\mathrm{kg}^{-1} \cdot \mathrm{h}^{-1}$, respectively) and in the $\mathrm{CHO}+\mathrm{PRO}$ trial $(303 \pm$ $26,294 \pm 14,264 \pm 14$, and $293 \pm 21 \mathrm{mg}$ protein $\cdot \mathrm{kg}^{-1} \cdot \mathrm{h}^{-1}$, respectively). However, in the $\mathrm{CHO}+\mathrm{PRO}$ trial, protein flux was increased $\sim 70 \%$ at rest, during exercise, and in the postexercise recovery phase compared with the $\mathrm{CHO}$ trial $(P<0.01)$.

Whole body protein synthesis $\left(\mathrm{mg}\right.$ protein $\left.\cdot \mathrm{kg}^{-1} \cdot \mathrm{h}^{-1}\right)$ in the $\mathrm{CHO}$ and $\mathrm{CHO}+\mathrm{PRO}$ studies is shown in Fig. $3 A$. No differences were found in protein synthesis rates during exercise compared with rest and the recovery phase. However, under all conditions, protein synthesis rates were higher in the $\mathrm{CHO}+\mathrm{PRO}$ trial than in the $\mathrm{CHO}$ trial $(P<0.01)$.

Protein degradation rates $\left(\mathrm{mg}\right.$ protein $\left.\cdot \mathrm{kg}^{-1} \cdot \mathrm{h}^{-1}\right)$ did not change during exercise (Fig. $3 B$ ). A marked decrease in protein breakdown was observed throughout the $\mathrm{CHO}+\mathrm{PRO}$ trial compared with the $\mathrm{CHO}$ trial $(P<0.01)$.

Whole body protein oxidation (mg protein $\left.\cdot \mathrm{kg}^{-1} \cdot \mathrm{h}^{-1}\right)$ is shown in Fig. 4. Whole body protein oxidation was similar at rest, during exercise, and during postexercise recovery in the $\mathrm{CHO}$ trial $(13 \pm 1,17 \pm 1,19 \pm 2$, and $15 \pm 2 \mathrm{mg}$ protein $\cdot \mathrm{kg}^{-1} \cdot \mathrm{h}^{-1}$, respectively) and in the $\mathrm{CHO}+\mathrm{PRO}$ trial $\left(31 \pm 4,30 \pm 3,25 \pm 2\right.$, and $27 \pm 3 \mathrm{mg}$ protein $\cdot \mathrm{kg}^{-1} \cdot \mathrm{h}^{-1}$, respectively). In the $\mathrm{CHO}+\mathrm{PRO}$ trial, protein oxidation rates were higher at rest, during exercise, and during recovery than in the CHO trial $(P<0.05)$.

During exercise, whole body protein balance (mg protein $\cdot \mathrm{kg}^{-1} \cdot \mathrm{h}^{-1}$ ) was not different from resting conditions and postexercise recovery (Fig. 5). Protein balance was positive in the $\mathrm{CHO}+\mathrm{PRO}$ trial and negative in the $\mathrm{CHO}$ trial.

Leucine model. Protein flux (mg protein $\cdot \mathrm{kg}^{-1} \cdot \mathrm{h}^{-1}$ ) was not different during exercise compared with rest and during postexercise recovery. Protein flux was $\sim 50 \%$ higher at rest, during exercise, and in the postexercise recovery phase $(P<$ 0.01) in the $\mathrm{CHO}+\mathrm{PRO}$ trial than in the $\mathrm{CHO}$ trial.

Whole body protein synthesis $\left(\mathrm{mg}\right.$ protein $\left.\cdot \mathrm{kg}^{-1} \cdot \mathrm{h}^{-1}\right)$ in the $\mathrm{CHO}$ and $\mathrm{CHO}+\mathrm{PRO}$ trials is shown in Fig. $3 A$. Protein synthesis rates were decreased during exercise compared with rest and postexercise recovery $(P<0.01)$. Whole body protein synthesis tended to be increased at rest in the $\mathrm{CHO}+\mathrm{PRO}$ trial $(P=0.09)$ but was similar during exercise and postexercise recovery in the $\mathrm{CHO}+\mathrm{PRO}$ and $\mathrm{CHO}$ trials.

Protein degradation rates $\left(\mathrm{mg}\right.$ protein $\left.\cdot \mathrm{kg}^{-1} \cdot \mathrm{h}^{-1}\right)$ did not change during exercise (Fig. $3 B$ ). A marked decrease in protein breakdown was observed throughout the $\mathrm{CHO}+\mathrm{PRO}$ trial compared with the $\mathrm{CHO}$ trial $(P<0.01)$.

Whole body protein oxidation $\left(\mathrm{mg}\right.$ protein $\left.\cdot \mathrm{kg}^{-1} \cdot \mathrm{h}^{-1}\right)$ is shown in Fig. 4. Protein oxidation rates were two- to threefold higher during exercise than at rest and during postexercise recovery $(P<0.01)$ in the $\mathrm{CHO}$ and $\mathrm{CHO}+\mathrm{PRO}$ trials. In the $\mathrm{CHO}+\mathrm{PRO}$ trial, protein oxidation was increased at rest, 
A
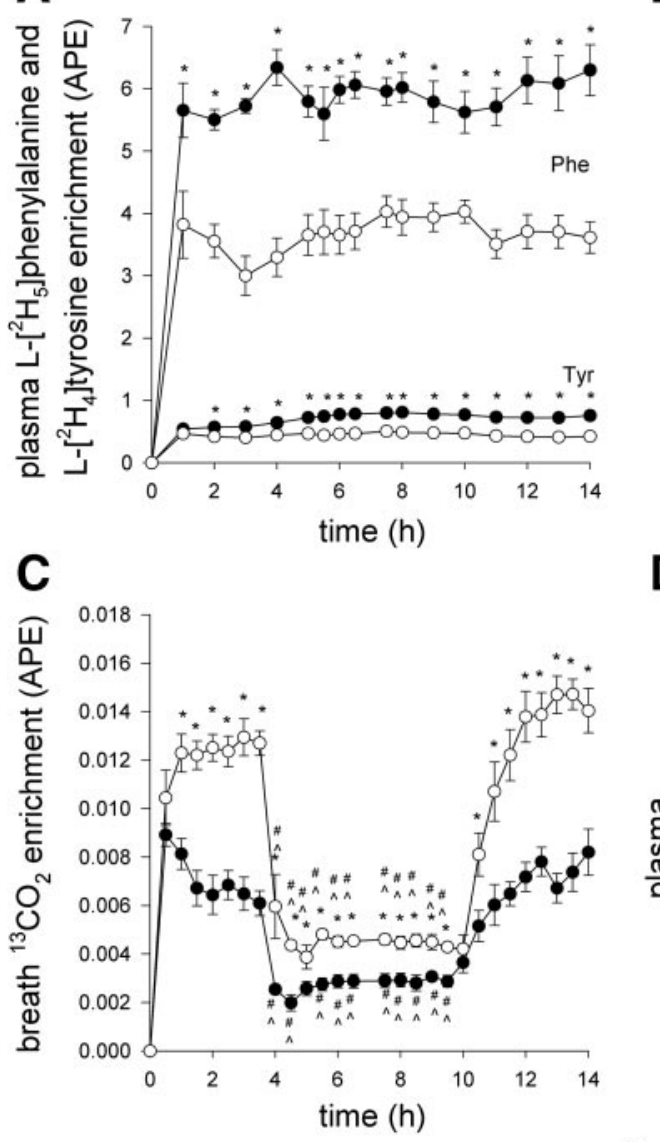

B

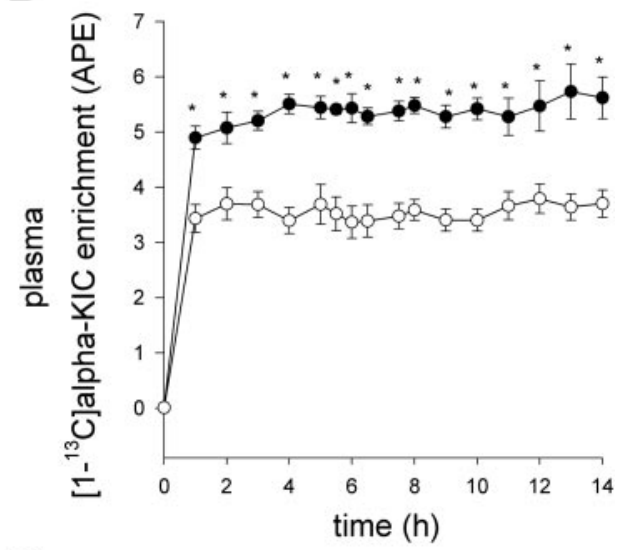

D

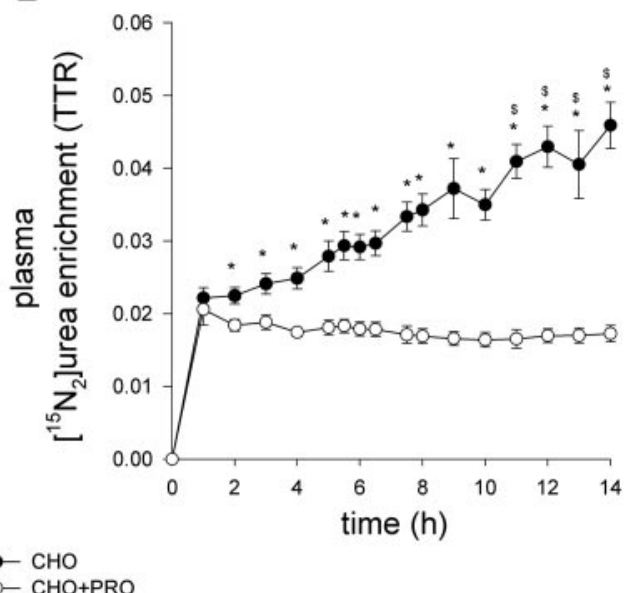

Fig. 2. Tracer data. A: plasma L- $\left[{ }^{2} \mathrm{H}_{5}\right]$ phenylalanine (Phe) and $\mathrm{L}-\left[{ }^{2} \mathrm{H}_{4}\right]$ tyrosine (Tyr) enrichment. $B$ : plasma ${ }^{13} \mathrm{C}$-labeled $\alpha$-ketoisocaproate $\left(\left[{ }^{13} \mathrm{C}\right] \mathrm{KIC}\right)$ enrichment. $C$ : breath ${ }^{13} \mathrm{CO}_{2}$ enrichment. $D$ : plasma $\left[{ }^{15} \mathrm{~N}_{2}\right]$ urea enrichment. APE, atom percent excess; TTR, tracer-to-tracee ratio. Values are means \pm SE. *Significantly different between studies $(P<0.05) .{ }^{\wedge}$ Significantly different from rest $(P<0.05)$. ${ }^{\#}$ Significantly different from recovery $(P<0.05)$. during exercise, and during recovery compared with the $\mathrm{CHO}$ trial $(P<0.05)$

In the CHO trial, whole body protein balance (mg protein $\cdot \mathrm{kg}^{-1} \cdot \mathrm{h}^{-1}$ ) was negative at rest, during exercise, and during subsequent recovery. Protein balance was more negative during exercise than at rest and during recovery $(P<0.01$; Fig. 5). In the $\mathrm{CHO}+\mathrm{PRO}$ trial, protein balance was less negative at rest, during exercise, and during postexercise recovery than in the $\mathrm{CHO}$ trial $(P<0.01)$; however, protein balance during exercise remained negative.
Phenylalanine model vs. leucine model. The relative increase in protein flux in the $\mathrm{CHO}+\mathrm{PRO}$ trial compared with the $\mathrm{CHO}$ trial was similar for both applied tracers: $+70 \pm 14 \%$ for $\mathrm{L}-\left[{ }^{2} \mathrm{H}_{5}\right]$ phenylalanine and $+48 \pm 12 \%$ for $\mathrm{L}-\left[1-{ }^{13} \mathrm{C}\right]$ leucine.

Protein synthesis was increased $69 \pm 14 \%$ in the $\mathrm{CHO}+$ PRO trial compared with the $\mathrm{CHO}$ trial when phenylalanine was used as a tracer. The leucine model showed no differences in protein synthesis rates between studies.

The relative decrease in protein degradation in the $\mathrm{CHO}+$ PRO trial compared with the $\mathrm{CHO}$ trial was similar for both
A

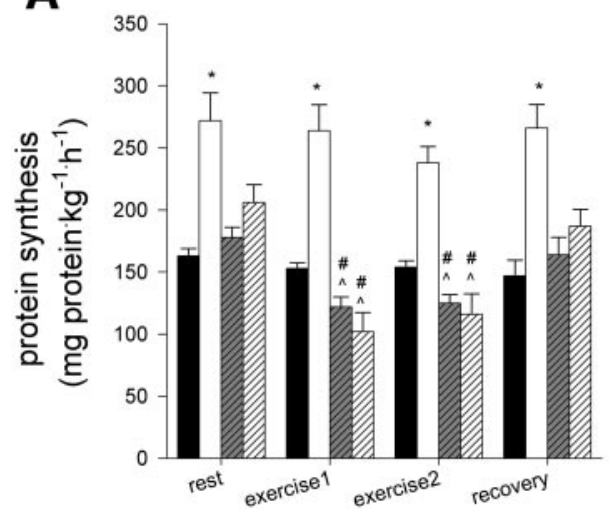

B

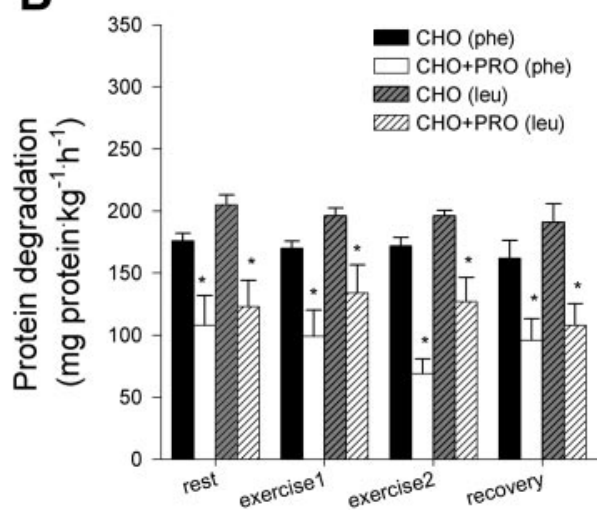

Fig. 3. Whole body protein synthesis $(A)$ and degradation $(B)$ calculated on the basis of L-[1-1 $\left.{ }^{13} \mathrm{C}\right]$ leucine (Leu) and L- $\left[{ }^{2} \mathrm{H}_{5}\right]$ phenylalanine at rest, during exercise, and during recovery. Values are means \pm SE. ${ }^{\wedge}$ Significantly different from rest $(P<0.01)$. ${ }^{\#} \mathrm{Sig}-$ nificantly different from recovery $(P<$ $0.01)$. *Significantly different between studies $(P<0.05)$. 


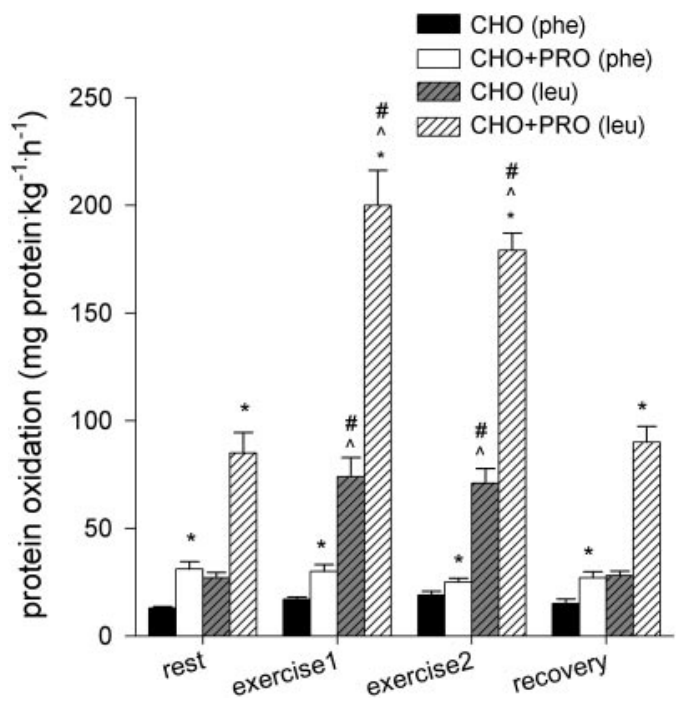

Fig. 4. Whole body protein oxidation calculated on the basis of L-[1$\left.{ }^{13} \mathrm{C}\right]$ leucine and $\mathrm{L}_{\mathrm{L}}\left[{ }^{2} \mathrm{H}_{5}\right]$ phenylalanine at rest, during exercise, and during recovery. Values are means $\pm \mathrm{SE}$. ${ }^{\wedge}$ Significantly different from rest $(P<$ $0.01)$. \#Significantly different from recovery $(P<0.01)$. *Significantly different between studies $(P<0.05)$

applied amino acid tracers: $-55 \pm 11 \%$ for $\mathrm{L}-\left[{ }^{2} \mathrm{H}_{5}\right]$ phenylalanine and $-62 \pm 8 \%$ for $\mathrm{L}-\left[1-{ }^{13} \mathrm{C}\right]$ leucine.

Protein oxidation was increased with both tracer models in the $\mathrm{CHO}+\mathrm{PRO}$ trial compared with the CHO trial. The increase in protein oxidation in the $\mathrm{CHO}+\mathrm{PRO}$ trial compared with the CHO trial was higher when measured with L- $\left[1-{ }^{13} \mathrm{C}\right]$ leucine than with $\mathrm{L}-\left[{ }^{2} \mathrm{H}_{5}\right]$ phenylalanine: $190 \pm 30 \%$ vs. $82 \pm 22 \%(P<0.05)$.

Protein balance was improved with both tracer models in the $\mathrm{CHO}+\mathrm{PRO}$ trial compared with the $\mathrm{CHO}$ trial $(P<0.05)$. The increase in protein balance in the $\mathrm{CHO}+$ PRO trial compared with the $\mathrm{CHO}$ trial was higher when measured with $\mathrm{L}-\left[{ }^{2} \mathrm{H}_{5}\right]$ phenylalanine than with L- $\left[1-{ }^{13} \mathrm{C}\right]$ leucine $(P<0.01)$.

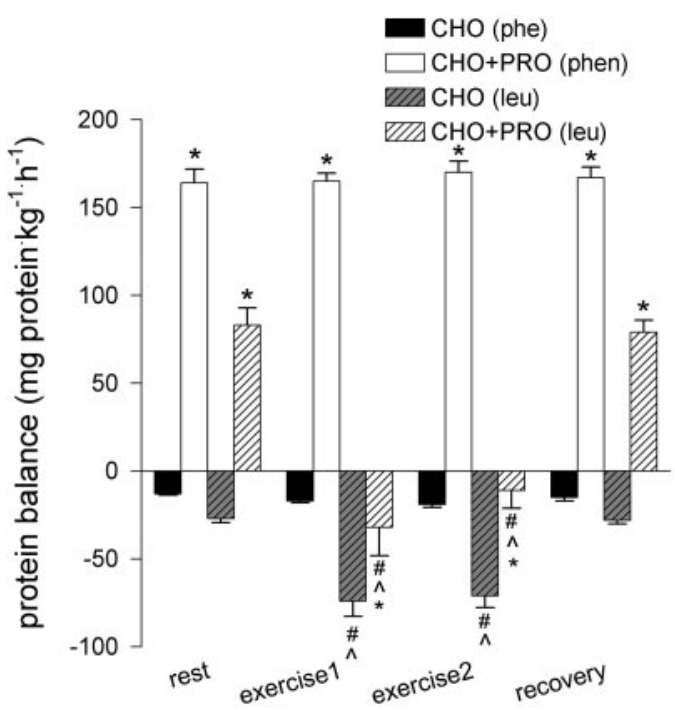

Fig. 5. Net whole body protein balance calculated on the basis of L-[1$\left.{ }^{13} \mathrm{C}\right]$ leucine and $\mathrm{L}-\left[{ }^{2} \mathrm{H}_{5}\right]$ phenylalanine at rest, during exercise, and during recovery. Values are means $\pm \mathrm{SE}$. ${ }^{\wedge}$ Significantly different from rest $(P<$ $0.01)$. " Significantly different from recovery $(P<0.01)$. *Significantly different between studies $(P<0.05)$.
Urea model and comparison with other tracers. Urea kinetics were calculated using a $\left[{ }^{15} \mathrm{~N}_{2}\right]$ urea tracer, and results are illustrated in Fig. 6. In the $\mathrm{CHO}$ trial, urea production decreased during exercise and recovery compared with resting values, whereas in the $\mathrm{CHO}+\mathrm{PRO}$ trial, urea production remained constant. Urea production was higher in the $\mathrm{CHO}+$ PRO trial than in the $\mathrm{CHO}$ trial $(\mathrm{P}<0.05)$.

Net protein balance calculated from urea production rates was less negative during exercise and recovery than at rest in the CHO trial $(P<0.05)$. No changes in net protein balance were observed in the $\mathrm{CHO}+\mathrm{PRO}$ trial. Calculated net protein balance was positive in the $\mathrm{CHO}+\mathrm{PRO}$ trial, whereas in the $\mathrm{CHO}$ trial net protein balance was negative.

In the CHO trial, whole body protein oxidation did not change in time with $\mathrm{L}-\left[{ }^{2} \mathrm{H}_{5}\right]$ phenylalanine applied as a tracer, increased during exercise with $\mathrm{L}-\left[1-{ }^{13} \mathrm{C}\right]$ leucine used as a tracer to return to resting values in the recovery period, and gradually decreased in time with $\left[{ }^{15} \mathrm{~N}_{2}\right]$ urea as tracer. In the CHO + PRO trial, whole body protein oxidation did not change in time with L- $\left[{ }^{2} \mathrm{H}_{5}\right]$ phenylalanine and $\left[{ }^{15} \mathrm{~N}_{2}\right]$ urea as tracers and increased during exercise with $\mathrm{L}-\left[1-{ }^{13} \mathrm{C}\right]$ leucine as tracer to return to resting values in the recovery period.

Protein balance was improved with all tracer models applied in the $\mathrm{CHO}+\mathrm{PRO}$ trial compared with the $\mathrm{CHO}$ trial. The phenylalanine model and the urea model indicate that the net protein balance is positive in the CHO + PRO trial at rest, during exercise, and during recovery.

\section{DISCUSSION}

In the present study, we show that whole body estimates of protein metabolism during exercise are highly dependent on the specific method and tracer that are applied. When $\mathrm{L}-\left[1-{ }^{13} \mathrm{C}\right]$ leucine was used as a tracer to study the effects of exercise on protein metabolism, protein oxidation was increased two- to threefold during exercise. However, when $\mathrm{L}-\left[{ }^{2} \mathrm{H}_{5}\right]$ phenylalanine was used as a tracer, protein oxidation, synthesis, and degradation rates were not affected by exercise. In addition, urea production, measured using $\left[{ }^{15} \mathrm{~N}_{2}\right]$ urea, decreased in time in the $\mathrm{CHO}$ trial. Thus two of the three methods

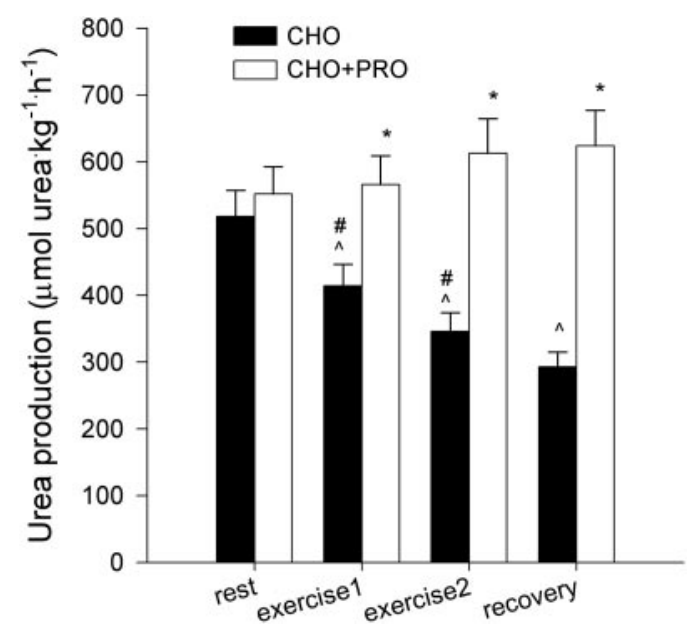

Fig. 6. Urea production calculated on the basis of $\left[{ }^{15} \mathrm{~N}_{2}\right]$ urea data at rest, during exercise, and during recovery. Values are means \pm SE. ^Significantly different from rest $(P<0.01)$. "Significantly different from recovery $(P<$ 0.01). *Significantly different between studies $(P<0.05)$. 
indicate that prolonged exhaustive exercise does not lead to increased protein oxidation and/or a more negative protein balance. Although the application of different tracer methods results in different effects of exercise on protein metabolism, each method shows that protein balance is negative when only carbohydrates are ingested. The addition of protein to carbohydrate ingestion improves whole body protein balance when measured using the phenylalanine and leucine models used in the present study.

Urea production in subjects not ingesting any protein is generally considered a reflection of the amount of amino acids that are liberated by net protein degradation (degradation synthesis) and subsequently oxidized with conversion of the amino group to urea. Studies on the effect of exercise on urea production have consistently found no significant change from the basal rate $(7,39,40)$, leading to the conclusion that the rate of net protein catabolism (degradation - synthesis) and amino acid oxidation was not changed. However, data obtained using another approach to determine whole body protein turnover, involving the infusion of $\mathrm{L}_{-}\left[1-{ }^{13} \mathrm{C}\right]$ leucine and the determination of leucine turnover and ${ }^{13} \mathrm{CO}_{2}$ appearance in the expired air, indicated that leucine oxidation was markedly increased during exercise $(4,5,39,40)$. Because of this discrepancy between methods, we applied both tracer methods in the same study. In addition, we also applied a third tracer, $\mathrm{L}-\left[{ }^{2} \mathrm{H}_{5}\right]$ phenylalanine, which has been successfully applied at rest $(10,27)$, but not during exercise conditions. In contrast to most studies, we used an experimental setup that included exercise and the continuous ingestion of carbohydrate $(\mathrm{CHO})$ or carbohydrate and protein supplements ( $\mathrm{CHO}+\mathrm{PRO})$, inasmuch as athletes always ingest carbohydrates during exercise (training or competition) of this duration and intensity. With leucine as tracer, protein oxidation was two- to threefold higher during exercise than at rest or during recovery (Fig. 4). The widely used $\mathrm{L}-\left[1-{ }^{13} \mathrm{C}\right]$ leucine model for the calculation of whole body protein synthesis and breakdown, therefore, suggests that exercise inhibits protein synthesis (Fig. 3A). However, with phenylalanine used as tracer, protein oxidation, synthesis, and degradation were similar at rest, during exercise, and during recovery (Figs. 4, 3A, and 3B, respectively). Moreover, urea production and the amount of protein oxidation calculated from it also did not increase during exercise (Fig. 6). Thus the phenylalanine model and urea data show that prolonged moderate-intensity exercise does not lead to an imbalance between protein synthesis and degradation and subsequent oxidation of the liberated amino acids. This is consistent with tracer incorporation studies $(8,30)$, which reported no change in muscle protein synthesis during moderate endurance exercise and recovery. However, results from the phenylalanine and leucine models in the present study show that whole body protein balance is negative at rest, during exercise, and during postexercise recovery when only carbohydrates are ingested (Fig. 5).

A severalfold increase in leucine oxidation without changes in urea production during exercise has been previously observed $(39,40)$. Moreover, other studies also showed no effect of exercise on plasma urea concentration (26), production (7), or urinary excretion $(6,18,23)$. An explanation for the discrepancy between the leucine and urea data is that leucine metabolism during exercise is not representative of the fate of the other amino acids that are present in proteins. The stochastic leucine model, therefore, cannot be used to investigate whole body protein metabolism during exercise. A difference in time response of leucine and urea kinetics theoretically also leads to an apparent absence of an increase in urea production during high rates of leucine oxidation. The urea pool is large and turns over with a half-life of $8-10 \mathrm{~h}(16,19,37)$. This implies that any increase in urea production due to an accelerated protein oxidation rate during exercise should have become apparent during or after the 6-h exercise period. However, in the $\mathrm{CHO}$ trial, we observed a gradual decrease, instead of an increase, in urea production over time. Such a decrease in urea production in time has previously been reported in studies at rest after an overnight fast (for references see Ref. 37). The latter can be attributed to the delayed response of the urea production after changes in protein intake $(16,37)$.

In the present study, we also investigated phenylalanine metabolism. We determined the rate of conversion (hydroxylation) of L- $\left[{ }^{2} \mathrm{H}_{5}\right]$ phenylalanine to $\mathrm{L}-\left[{ }^{2} \mathrm{H}_{4}\right]$ tyrosine at rest, during exercise, and during recovery. This is the first step of phenylalanine oxidation, and we found that its rate did not change during exercise and/or recovery compared with the resting state. This is consistent with findings reported by Wolfe et al. (40) using a lysine tracer. In the latter study, the increase in lysine oxidation during exercise was small compared with the increase in leucine oxidation. In addition, a discrepancy existed between the $\left[{ }^{15} \mathrm{~N}\right]$ - and $\left[{ }^{13} \mathrm{C}\right]$ lysine flux data and the $\left[{ }^{13} \mathrm{C}\right]-$ and $\left[{ }^{15} \mathrm{~N}\right]$ leucine flux data that was similar to the discrepancy between phenylalanine and leucine observed in the present study.

One of the likely causes of the discrepancy between the lysine and phenylalanine tracer and the leucine tracer methods is a severalfold increase in uptake $(1,32)$ and oxidation $(32,34$, 35) of branched-chain amino acids (leucine, isoleucine, and valine) during exercise in contracting muscle. As such, the leucine tracer does not seem to be representative of the fate of the other essential amino acids during exercise. The latter means that the stochastic leucine model of whole body protein metabolism (20) becomes invalid during exercise and cannot be used to estimate qualitative or quantitative changes in whole body protein synthesis and/or degradation.

Most studies measuring protein turnover during exercise were performed in the morning after an overnight fast, which does not represent everyday practice in competitive athletes. Athletes optimize carbohydrate availability before and during exercise to enhance endurance performance capacity. During subsequent recovery, they ingest mixed meals or carbohydrate/ protein recovery drinks. The present study demonstrates that net protein degradation does not increase during moderateintensity exercise when carbohydrate is ingested. This implies that net protein breakdown and oxidation are minimal during athletic events such as (ultra)marathons and prolonged cycling races when carbohydrate is ingested. Although protein degradation and synthesis are unaltered by exercise when carbohydrate $(0.7 \mathrm{~g} / \mathrm{min})$ is ingested, whole body protein balance measured with L- $\left[{ }^{2} \mathrm{H}_{5}\right]$ phenylalanine was slightly negative during exercise and during recovery in the present study. However, the imbalance between protein synthesis and degradation and the amount of protein oxidized was not larger than in the resting state (Fig. 5).

It has previously been shown that infusion or ingestion of amino acids alone or in combination with carbohydrate increases protein synthesis and reduces protein degradation at a 
whole body level and in skeletal muscle tissue under resting conditions $(12,15,22)$ and after resistance exercise $(2,3,24$, $28,29)$, resulting in a positive protein balance. We aimed to investigate whether the addition of protein to a carbohydrate supplement can improve whole body protein balance during and after prolonged endurance exercise leading to a (more) positive protein balance, as previously observed in the resting state. Combined ingestion of protein and carbohydrate resulted in an increased whole body protein synthesis rate at rest, during exercise, and during recovery compared with carbohydrate supplementation only. Although protein oxidation was increased almost twofold at rest, during exercise, and during recovery with the protein supplement, whole body protein degradation decreased by $\sim 60 \%$. Thus the present study shows that the combined ingestion of protein and carbohydrate improves net protein balance at rest, during prolonged moderateintensity exercise, and during subsequent recovery in elite endurance athletes. With phenylalanine and urea as tracers, a positive net protein balance was achieved, whereas ingestion of only carbohydrate resulted in a negative protein balance.

The $\mathrm{L}-\left[{ }^{2} \mathrm{H}_{5}\right]$ phenylalanine tracer method indicates that protein flux and oxidation rates are increased as expected when protein is orally ingested. In addition, coingestion of protein and carbohydrate results in a decreased rate of protein degradation and improved protein balance. The $\left[{ }^{15} \mathrm{~N}_{2}\right]$ urea tracer provides an effect of exercise on net protein balance similar to that when L- $\left[{ }^{2} \mathrm{H}_{5}\right]$ phenylalanine is used as tracer. Urea production slightly increases when protein is ingested (Fig. 6), because more protein is ingested than is used for protein synthesis. The excess is directly oxidized or used for gluconeogenesis and/or lipogenesis, with the amino group being excreted as urea. The balance between protein synthesis and degradation calculated from the difference between urea production observed and the urea equivalent of the ingested amount of protein (Table 2) indicates net positive protein balance, which is quantitatively similar to the estimates made from the values generated by the phenylalanine tracer at rest, during exercise, and during recovery. This implies that the information generated by the phenylalanine tracer and urea tracer on the effect of protein ingestion is similar in all time periods studied, whereas the leucine data generate a different message during exercise: positive balance at rest and during recovery and negative balance during exercise.

In summary, this study shows that the $\mathrm{L}-\left[{ }^{2} \mathrm{H}_{5}\right]$ phenylalanine, $\mathrm{L}-\left[1-{ }^{13} \mathrm{C}\right]$ leucine, and $\left[{ }^{15} \mathrm{~N}_{2}\right]$ urea tracer models reveal the same qualitative effect of the combined ingestion of protein and carbohydrate on whole body protein balance at rest and during recovery. However, the $\mathrm{L}-\left[1-{ }^{13} \mathrm{C}\right]$ leucine model for measurements of whole body protein turnover overestimates protein oxidation rates and underestimates protein synthesis rates during exercise. We conclude that prolonged exhaustive moderate-intensity exercise does not result in an increase in protein degradation and/or a decrease in protein synthesis compared with resting situations in endurance-trained athletes. Whereas whole body protein balance remains negative when only carbohydrates are ingested, coingestion with protein improves protein balance by increasing synthesis and decreasing breakdown, resulting in a positive net protein balance at rest, during prolonged moderate-intensity exercise, and during recovery.

\section{APPENDIX}

Calculations. The rate of protein turnover was calculated as described previously (20). Briefly, leucine turnover (flux, $Q$ ) was measured from the dilution of $\mathrm{L}-\left[1-{ }^{13} \mathrm{C}\right]$ leucine infusion in plasma $\alpha$-KIC at isotopic steady state

$$
Q=\mathrm{i} \cdot\left(\frac{\mathrm{E}_{\mathrm{i}}}{\mathrm{E}_{\mathrm{p}}}-1\right)
$$

where $\mathrm{i}$ is the $\left[1{ }^{13} \mathrm{C}\right]$ leucine infusion rate $\left(\mu \mathrm{mol} \cdot \mathrm{kg}\right.$ body $\left.\mathrm{wt}^{-1} \cdot \mathrm{h}^{-1}\right)$, $\mathrm{E}_{\mathrm{i}}$ is the enrichment of the $\left[1{ }^{13} \mathrm{C}\right]$ leucine infused [expressed in atom percent excess (APE)], and $\mathrm{E}_{\mathrm{p}}$ is the $\left[1-{ }^{13} \mathrm{C}\right] \alpha-\mathrm{KIC}$ enrichment in the plasma at steady state (APE). The background enrichment of expired ${ }^{13} \mathrm{CO}_{2}$ was measured before the start of tracer infusions. This background enrichment was subtracted from the isotopic plateau value for the calculation of leucine oxidation. Leucine oxidation rates were also corrected for bicarbonate retention. In endurance-trained subjects, bicarbonate retention factors were $83.1 \%$ for rest and $98.9 \%$ for exercise (11). The rate of leucine oxidation $(\mathrm{O})$ is calculated as follows

Table 2. Protein metabolism at rest, during exercise, and during subsequent recovery

\begin{tabular}{|c|c|c|c|c|c|c|c|c|c|c|}
\hline & \multicolumn{2}{|c|}{$\begin{array}{l}\text { Protein Oxidation, } \\
\mathrm{mg} \text { protein } \cdot \mathrm{kg}^{-1} \cdot \mathrm{h}^{-1}\end{array}$} & \multicolumn{2}{|c|}{$\begin{array}{l}\text { Protein Synthesis, } \\
\text { mg protein } \mathrm{kg}^{-1} \cdot \mathrm{h}^{-1}\end{array}$} & \multicolumn{2}{|c|}{$\begin{array}{l}\text { Protein Degradation, } \\
\mathrm{mg} \text { protein } \mathrm{kg}^{-1} \cdot \mathrm{h}^{-1}\end{array}$} & \multicolumn{2}{|c|}{$\begin{array}{l}\text { Protein Balance, } \\
\mathrm{mg} \text { protein } \cdot \mathrm{kg}^{-1} \cdot \mathrm{h}^{-1}\end{array}$} & \multicolumn{2}{|c|}{$\begin{array}{l}\text { Urea Production, } \\
\mu \mathrm{mol} \cdot \mathrm{kg}^{-1} \cdot \mathrm{h}^{-1}\end{array}$} \\
\hline & $\mathrm{CHO}$ & $\mathrm{CHO}+\mathrm{PRO}$ & $\mathrm{CHO}$ & $\mathrm{CHO}+\mathrm{PRO}$ & $\mathrm{CHO}$ & $\mathrm{CHO}+\mathrm{PRO}$ & $\mathrm{CHO}$ & $\mathrm{CHO}+\mathrm{PRO}$ & $\mathrm{CHO}$ & $\mathrm{CHO}+\mathrm{PRO}$ \\
\hline Rest & $13 \pm 0.7$ & $31 \pm 3.5^{*}$ & $163 \pm 6.0$ & $272 \pm 22.3 *$ & $176 \pm 6.0$ & $108 \pm 24.0^{*}$ & $-13 \pm 0.7$ & $164 \pm 7.8^{*}$ & NA & NA \\
\hline Exercise 1 & $17 \pm 1.1$ & $30 \pm 3.2 *$ & $153 \pm 4.6$ & $264 \pm 20.9^{*}$ & $170 \pm 5.7$ & $99 \pm 21.2^{*}$ & $-17 \pm 1.1$ & $165 \pm 4.6^{*}$ & NA & NA \\
\hline Exercise 2 & $19 \pm 1.8$ & $25 \pm 1.8^{*}$ & $154 \pm 5.3$ & $238 \pm 13.1^{*}$ & $172 \pm 6.7$ & $69 \pm 12.0 *$ & $-19 \pm 1.8$ & $170 \pm 6.4^{*}$ & NA & NA \\
\hline Recovery & $15 \pm 2.1$ & $27 \pm 2.8 *$ & $147 \pm 12.7$ & $266 \pm 19.1^{*}$ & $162 \pm 14.5$ & $96 \pm 17.3^{*}$ & $-15 \pm 2.1$ & $167 \pm 6.0 *$ & NA & NA \\
\hline Exercise 1 & $74 \pm 8.8+\ddagger$ & $200 \pm 16.3^{*}+\ddagger$ & $122 \pm 8.1 \dagger \neq$ & $102 \pm 15.6+t$ & $196 \pm 6.4$ & $134 \pm 22.6^{*}$ & $-74 \pm 8.8+\ddagger$ & $-32 \pm 16.3 * \dagger+$ & NA & NA \\
\hline Exercise 2 & $71 \pm 6.7 \dagger t$ & $179 \pm 8.1 * \dagger \neq$ & $125 \pm 7.1 \dagger+$ & $116 \pm 16.6 \dagger t$ & $196 \pm 4.6$ & $127 \pm 19.4 *$ & $-71 \pm 6.7 \dagger+$ & $-11 \pm 10.3 * \dagger \dagger$ & NA & NA \\
\hline Recovery & $28 \pm 2.1$ & $90 \pm 7.4 *$ & $164 \pm 14.1$ & $187 \pm 13.4$ & $191 \pm 14.8$ & $108 \pm 17.3 *$ & $-28 \pm 2.1$ & $79 \pm 6.7 *$ & NA & NA \\
\hline \multicolumn{11}{|l|}{ Urea } \\
\hline Rest & NA & NA & NA & NA & NA & NA & $-91 \pm 6.8$ & $154 \pm 13.7 *$ & $518 \pm 39$ & $552 \pm 41$ \\
\hline Exercise 1 & NA & NA & NA & NA & NA & NA & $-72 \pm 5.7$ & $151 \pm 13.4^{*}$ & $414 \pm 33+\neq$ & $566 \pm 43^{*}$ \\
\hline Exercise 2 & NA & NA & NA & NA & NA & NA & $-61 \pm 4.9 \dagger$ & $143 \pm 14.5^{*}$ & $346 \pm 28+t$ & $613 \pm 52 *$ \\
\hline
\end{tabular}

Values are means $\pm \mathrm{SE}(n=8)$. CHO, carbohydrate trial; $\mathrm{CHO}+\mathrm{PRO}$, carbohydrate and protein trial; NA, not applicable. *Significantly different between studies $(P<0.05)$. $†$ Significantly different from rest $(P<0.01)$. $¥$ Significantly different from recovery $(P<0.01)$. 


$$
\mathrm{O}=F^{13} \mathrm{CO}_{2} \cdot\left[\left(\frac{1}{\mathrm{E}_{\mathrm{p}}}\right)-\left(\frac{1}{\mathrm{E}_{\mathrm{i}}}\right)\right] \cdot 100
$$

where $F^{13} \mathrm{CO}_{2}$ is the rate of ${ }^{13} \mathrm{CO}_{2}$ production and release in the expired breath $\left(\mu \mathrm{mol}{ }^{13} \mathrm{CO}_{2} \cdot \mathrm{kg}\right.$ body $\left.\mathrm{wt}^{-1} \cdot \mathrm{h}^{-1}\right)$. At isotopic steady state, protein $\dot{Q}$ equals the sum of protein synthesis (S) and $\mathrm{O}$ as well as the sum of the rate of appearance of meal protein from the gut (I) and protein breakdown (B); whole body protein synthesis rate was calculated as flux - oxidation

$$
\begin{aligned}
& \dot{Q}=\mathrm{S}+\mathrm{O}=\mathrm{B}+\mathrm{I} \\
& \mathrm{S}=Q-\mathrm{O}
\end{aligned}
$$

The leucine parameters mentioned above were converted to corresponding estimates of whole body protein turnover by multiplying the leucine values by the constant $1 /(590 \mu \mathrm{mol}$ leucine/g protein $)$ to give grams of protein per kilogram per hour (20). The $590 \mu \mathrm{mol}$ of leucine per gram protein factor corresponds to a protein leucine content of $7.8 \%$ and was derived from averaged values for leucine content of protein of human and other mammalian muscles (20).

In addition, we used the phenylalanine balance model as described by Thompson et al. (27). In this model, phenylalanine $Q\left(Q_{\mathrm{p}}\right)$ can be calculated by isotope dilution using Eq. 1 , where $i$ is the $\mathrm{L}-\left[{ }^{2} \mathrm{H}_{5}\right]$ phenylalanine infusion rate $\left(\mu \mathrm{mol} \cdot \mathrm{kg}^{-1} \cdot \mathrm{h}^{-1}\right), \mathrm{E}_{\mathrm{i}}$ is the enrichment of the $\mathrm{L}-\left[{ }^{2} \mathrm{H}_{5}\right]$ phenylalanine infused (expressed in APE), and $\mathrm{E}_{\mathrm{p}}$ is the $\mathrm{L}-\left[{ }^{2} \mathrm{H}_{5}\right]$ phenylalanine in the plasma at steady state (APE). At isotopic steady state, whole body phenylalanine oxidation can be determined from the conversion (hydroxylation) of $\mathrm{L}-\left[{ }^{2} \mathrm{H}_{5}\right]$ phenylalanine to $\mathrm{L}-\left[{ }^{2} \mathrm{H}_{4}\right]$ tyrosine. The rate of hydroxylation $\left(Q_{\mathrm{pt}}\right)$ was calculated (27) using the formula

$$
\dot{Q}_{\mathrm{pt}}=\frac{\mathrm{P}_{\mathrm{t}} \cdot \dot{Q}_{\mathrm{p}}^{2}}{\mathrm{P}_{\mathrm{p}} \cdot\left(\frac{\mathrm{E}_{\mathrm{p}}}{\mathrm{E}_{\mathrm{t}}}-1\right) \cdot\left(i_{\mathrm{p}}-\dot{Q}_{\mathrm{p}}\right)}
$$

where $\mathrm{P}_{\mathrm{t}} / \mathrm{P}_{\mathrm{p}}(0.73)$ is the molar ratio of tyrosine $Q$ to $Q_{p}$ arising from protein catabolism (27), $\mathrm{E}_{\mathrm{t}}$ is the $\mathrm{L}-\left[{ }^{2} \mathrm{H}_{4}\right]$ tyrosine enrichment, and $i_{\mathrm{p}}$ is the $\mathrm{L}-\left[{ }^{2} \mathrm{H}_{5}\right]$ phenylalanine infusion rate $\left(\mu \mathrm{mol} \cdot \mathrm{kg}^{-1} \cdot \mathrm{h}^{-1}\right)$. Protein synthesis-and-degradation using this approach was calculated as follows

$$
\dot{Q}=\mathrm{S}+\dot{Q}_{\mathrm{pt}}=\mathrm{B}+\mathrm{I}
$$

Rates of protein synthesis and degradation (g protein $\cdot \mathrm{kg}$ body weight $^{-1} \cdot \mathrm{h}^{-1}$ ) are calculated using the phenylalanine content of protein of $280 \mu \mathrm{mol} / \mathrm{g}$ protein (27). The $280 \mu \mathrm{mol}$ phenylalanine/g protein factor was derived from protein composition measurements in animals (21).

The net protein balance (Table 2) was calculated from the difference between whole body protein synthesis and degradation determined using the leucine and phenylalanine model as described above.

The rate of urea production was calculated using equations described previously (38). Briefly, at isotopic steady state during the constant infusion of $\left[{ }^{15} \mathrm{~N}_{2}\right]$ urea, two enrichments (expressed in tracerto-tracee ratio) were measured, $A$ and $B$

$$
\begin{aligned}
& A=\frac{\text { singly labeled urea }}{\text { unlabeled urea }} \\
& B=\frac{\text { doubly labeled urea }}{\text { unlabeled urea }}
\end{aligned}
$$

The rate of urea production was calculated using

$$
Q=\frac{2 F}{A+2 B}
$$

where $F$ is the $\left[{ }^{15} \mathrm{~N}_{2}\right]$ urea infusion rate $\left(\mu \mathrm{mol} \cdot \mathrm{kg}^{-1} \cdot \mathrm{h}^{-1}\right)$.

The net balance of the amount $\left(\mathrm{g} \cdot \mathrm{kg}^{-1} \cdot \mathrm{h}^{-1}\right)$ of protein that was broken down in the $\mathrm{CHO}$ trial and converted to urea was calculated by converting urea production rates to milligrams of nitrogen produced per kilogram per hour and multiplying by 6.25 ( $1 \mathrm{~g}$ of protein contains $160 \mathrm{mg}$ of nitrogen). The positive protein net balance (protein synthesis - protein degradation) reported in Table 2 was calculated in this case by again converting the observed urea production rate to protein oxidation rates and then taking the difference between protein ingestion and protein oxidation (both in $\mathrm{g}$ protein $\cdot \mathrm{kg}^{-1} \cdot \mathrm{h}^{-1}$ ).

\section{ACKNOWLEDGMENTS}

We gratefully acknowledge the analytic assistance of Jos Stegen and the enthusiastic support of the subjects who volunteered to participate in these studies.

Present addresses: A. J. M. Wagenmakers and A. E. Jeukendrup, School of Sport and Exercise Sciences, University of Birmingham, Birmingham, B15 2TT, UK; D. Halliday, Tropical Metabolism Research Unit, University of the West Indies, Mona, Kingston 7, Jamaica.

\section{REFERENCES}

1. Ahlborg G, Felig P, Hagenfeldt L, Hendler R, and Wahren J. Substrate turnover during prolonged exercise in man. Splanchnic and leg metabolism of glucose, free fatty acids, and amino acids. J Clin Invest 53: 1080-1090, 1974.

2. Biolo G, Tipton KD, Klein S, and Wolfe RR. An abundant supply of amino acids enhances the metabolic effect of exercise on muscle protein. Am J Physiol Endocrinol Metab 273: E122-E129, 1997.

3. Borsheim E, Tipton KD, Wolf SE, and Wolfe RR. Essential amino acids and muscle protein recovery from resistance exercise. Am J Physiol Endocrinol Metab 283: E648-E657, 2002.

4. Bowtell JL, Leese GP, Smith K, Watt PW, Nevill A, Rooyackers O, Wagenmakers AJ, and Rennie MJ. Effect of oral glucose on leucine turnover in human subjects at rest and during exercise at two levels of dietary protein. J Physiol 525: 271-281, 2000.

5. Bowtell JL, Leese GP, Smith K, Watt PW, Nevill A, Rooyackers O, Wagenmakers AJ, and Rennie MJ. Modulation of whole body protein metabolism, during and after exercise, by variation of dietary protein. J Appl Physiol 85: 1744-1752, 1998.

6. Carraro F, Hartl WH, Stuart CA, Layman DK, Jahoor F, and Wolfe RR. Whole body and plasma protein synthesis in exercise and recovery in human subjects. Am J Physiol Endocrinol Metab 258: E821-E831, 1990.

7. Carraro F, Kimbrough TD, and Wolfe RR. Urea kinetics in humans at two levels of exercise intensity. J Appl Physiol 75: 1180-1185, 1993.

8. Carraro F, Stuart CA, Hartl WH, Rosenblatt J, and Wolfe RR. Effect of exercise and recovery on muscle protein synthesis in human subjects. Am J Physiol Endocrinol Metab 259: E470-E476, 1990.

9. Cathcart EP. The influence of muscle work on protein metabolism. Physiol Rev 5: 225-243, 1925.

10. Clarke JT and Bier DM. The conversion of phenylalanine to tyrosine in man. Direct measurement by continuous intravenous tracer infusions of L-[ring- $\left.{ }^{2} \mathrm{H}_{5}\right]$ phenylalanine and $\mathrm{L}-\left[1-{ }^{13} \mathrm{C}\right]$ tyrosine in the postabsorptive state. Metabolism 31: 999-1005, 1982.

11. Coggan AR, Habash DL, Mendenhall LA, Swanson SC, and Kien CL. Isotopic estimation of $\mathrm{CO}_{2}$ production during exercise before and after endurance training. J Appl Physiol 75: 70-75, 1993.

12. Collin-Vidal C, Cayol M, Obled C, Ziegler F, Bommelaer G, and Beaufrere B. Leucine kinetics are different during feeding with whole protein or oligopeptides. Am J Physiol Endocrinol Metab 267: E907E914, 1994.

13. Decombaz J, Reinhardt P, Anantharaman K, von Glutz G, and Poortmans JR. Biochemical changes in a 100-km run: free amino acids, urea, and creatinine. Eur J Appl Physiol 41: 61-72, 1979.

14. Fick A and Wislecenus J. On the origin of muscular power. Philos Mag 31: 485-503, 1866.

15. Fryburg DA, Jahn LA, Hill SA, Oliveras DM, and Barrett EJ. Insulin and insulin-like growth factor-I enhance human skeletal muscle protein anabolism during hyperaminoacidemia by different mechanisms. J Clin Invest 96: 1722-1729, 1995.

16. Jones EA, Craigie A, Tavill AS, Simon W, and Rosenoer VM. Urea kinetics and the direct measurement of the synthetic rate of albumin utilizing $\left[{ }^{14} \mathrm{C}\right]$ carbonate. Clin Sci 35: 553-564, 1968.

17. Kuipers H, Verstappen FT, Keizer HA, Geurten P, and van Kranenburg G. Variability of aerobic performance in the laboratory and its physiologic correlates. Int J Sports Med 6: 197-201, 1985. 
18. Lemon PW and Mullin JP. Effect of initial muscle glycogen levels on protein catabolism during exercise. J Appl Physiol 48: 624-629, 1980.

19. Matthews DE and Downey RS. Measurement of urea kinetics in humans: a validation of stable isotope tracer methods. Am J Physiol Endocrinol Metab 246: E519-E527, 1984.

20. Matthews DE, Motil KJ, Rohrbaugh DK, Burke JF, Young VR, and Bier DM. Measurement of leucine metabolism in man from a primed, continuous infusion of L- $\left[1-{ }^{13} \mathrm{C}\right]$ leucine. Am J Physiol Endocrinol Metab 238: E473-E479, 1980.

21. Munro HN and Fleck A. Analysis of tissues and body fluids for nitrogenous constituents. In: Mammalian Protein Metabolism, edited by Munro HN. New York: Academic, 1969, p. 423-525.

22. Pacy PJ, Garrow JS, Ford GC, Merritt H, and Halliday D. Influence of amino acid administration on whole-body leucine kinetics and resting metabolic rate in postabsorptive normal subjects. Clin Sci (Lond) 75: 225-231, 1988.

23. Phillips SM, Atkinson SA, Tarnopolsky MA, and MacDougall JD. Gender differences in leucine kinetics and nitrogen balance in endurance athletes. J Appl Physiol 75: 2134-2141, 1993.

24. Rasmussen BB, Tipton KD, Miller SL, Wolf SE, and Wolfe RR. An oral essential amino acid-carbohydrate supplement enhances muscle protein anabolism after resistance exercise. J Appl Physiol 88: 386-392, 2000.

25. Rennie MJ, Edwards RH, Krywawych S, Davies CT, Halliday D, Waterlow JC, and Millward DJ. Effect of exercise on protein turnover in man. Clin Sci (Lond) 61: 627-639, 1981.

26. Stein TP, Hoyt RW, Toole MO, Leskiw MJ, Schluter MD, Wolfe RR, and Hiller WD. Protein and energy metabolism during prolonged exercise in trained athletes. Int J Sports Med 10: 311-316, 1989.

27. Thompson GN, Pacy PJ, Merritt H, Ford GC, Read MA, Cheng KN, and Halliday D. Rapid measurement of whole body and forearm protein turnover using a $\left[{ }^{2} \mathrm{H}_{5}\right]$ phenylalanine model. Am J Physiol Endocrinol Metab 256: E631-E639, 1989.

28. Tipton KD, Borsheim E, Wolf SE, Sanford AP, and Wolfe RR. Acute response of net muscle protein balance reflects 24-h balance after exercise and amino acid ingestion. Am J Physiol Endocrinol Metab 284: E76-E89, 2003
29. Tipton KD, Ferrando AA, Phillips SM, Doyle D Jr, and Wolfe RR. Postexercise net protein synthesis in human muscle from orally administered amino acids. Am J Physiol Endocrinol Metab 276: E628-E634, 1999.

30. Tipton KD, Ferrando AA, Williams BD, and Wolfe RR. Muscle protein metabolism in female swimmers after a combination of resistance and endurance exercise. J Appl Physiol 81: 2034-2038, 1996.

31. Van Acker BA, Hulsewe KW, Wagenmakers AJ, Soeters PB, and von Meyenfeldt MF. Glutamine appearance rate in plasma is not increased after gastrointestinal surgery in humans. J Nutr 130: 1566-1571, 2000.

32. Van Hall G, MacLean DA, Saltin B, and Wagenmakers AJ. Mechanisms of activation of muscle branched-chain $\alpha$-keto acid dehydrogenase during exercise in man. $J$ Physiol 494: 899-905, 1996.

33. Von Liebig J. Animal Chemistry or Organic Chemistry in Its Application to Physiology. London: Taylor and Walton, 1842.

34. Wagenmakers AJ, Beckers EJ, Brouns F, Kuipers H, Soeters PB, van der Vusse GJ, and Saris WH. Carbohydrate supplementation, glycogen depletion, and amino acid metabolism during exercise. Am J Physiol Endocrinol Metab 260: E883-E890, 1991.

35. Wagenmakers AJ, Brookes JH, Coakley JH, Reilly T, and Edwards RH. Exercise-induced activation of the branched-chain 2-oxo acid dehydrogenase in human muscle. Eur J Appl Physiol 59: 159-167, 1989.

36. Wagenmakers AJ, Rehrer NJ, Brouns F, Saris WH, and Halliday D. Breath ${ }^{13} \mathrm{CO}_{2}$ background enrichment during exercise: diet-related differences between Europe and America. J Appl Physiol 74: 2353-2357, 1993.

37. Waterlow JC. The mysteries of nitrogen balance. Nutr Res Rev 12: 25-54, 1999.

38. Wolfe RR. Radioactive and Stable Isotope Tracers in Biomedicine: Principles and Practice of Kinetic Analysis. New York: Wiley-Liss, 1992.

39. Wolfe RR, Goodenough RD, Wolfe MH, Royle GT, and Nadel ER. Isotopic analysis of leucine and urea metabolism in exercising humans. J Appl Physiol 52: 458-466, 1982.

40. Wolfe RR, Wolfe MH, Nadel ER, and Shaw JH. Isotopic determination of amino acid-urea interactions in exercise in humans. $J$ Appl Physiol 56: 221-229, 1984. 